\title{
A!
}

This is an electronic reprint of the original article.

This reprint may differ from the original in pagination and typographic detail.

Pullins, Ellen Bolman; Timonen, Hanna; Kaski, Timo; Holopainen, Mari

\section{An Investigation of the Theory Practice Gap in Professional Sales}

Published in:

JOURNAL OF MARKETING THEORY AND PRACTICE

DOI:

$10.1080 / 10696679.2016 .1236665$

Published: 01/01/2017

Document Version

Peer reviewed version

Please cite the original version:

Pullins, E. B., Timonen, H., Kaski, T., \& Holopainen, M. (2017). An Investigation of the Theory Practice Gap in Professional Sales. JOURNAL OF MARKETING THEORY AND PRACTICE, 25(1), 17-38.

https://doi.org/10.1080/10696679.2016.1236665

This material is protected by copyright and other intellectual property rights, and duplication or sale of all or part of any of the repository collections is not permitted, except that material may be duplicated by you for your research use or educational purposes in electronic or print form. You must obtain permission for any other use. Electronic or print copies may not be offered, whether for sale or otherwise to anyone who is not an authorised user. 
An Investigation of the Theory-Practice Gap in Professional Sales*

*Paper accepted for publication in Journal of Marketing Theory and Practice

Ellen Bolman Pullins, Ph.D., Schmidt Research Professor of Sales and Sales Management ${ }^{1}$

College of Business and Innovation MS 103

The University of Toledo

$2801 \mathrm{~W}$. Bancroft St.

Toledo, Ohio 43606 USA

419.530.4274

FAX 419.530.4610

ellen.pullins@utoledo.edu

Hanna Timonen, Doctoral Candidate

Department of Industrial Engineering and Management

Aalto University School of Science

P.O. Box 15500, FIN-00076 Aalto, Finland

$+358503709696$

hanna.timonen@aalto.fi

Timo Kaski, D.Sc. (Etch.), Research Manager

Sales and Services

HAAGA-HELIA University of Applied Sciences

Ratapihantie 13

FIN-00520 Helsinki, Finland

$+358404887594$

timo.kaski@haaga-helia.fi

Mari Holopainen, Doctoral Candidate

Department of Industrial Engineering and Management

Aalto University School of Science

P.O. Box 15500, FIN-00076 Aalto, Finland

$+358407620944$

mari.holopainen@aalto.fi

${ }^{1}$ Corresponding Author

\section{Acknowledgements}

The authors wish to thank both the companies that participated in the Mania research project and Tekes, the Finnish Funding Agency for Technology and Innovation, for supporting this research. 
An Investigation of the Theory-Practice Gap in Professional Sales

\begin{abstract}
This paper considers the theory-practice gap in professional sales. Scholars note a discrepancy between scholarly knowledge and the practice of selling. We study three exemplar gaps using an extensive qualitative dataset, mainly in-depth interviews, in order to better understand why these gaps exist. Theory-practice gaps in listening, follow-up, and adaptability have not been empirically confirmed in light of rapid change in the sales field. After confirming these gaps, we explore antecedents, uncovering several underlying reasons for gap formation. We consider theoretical and managerial implications. In particular, we elaborate on the need for theory to be more relevant and contextualized.
\end{abstract}


An Investigation of the Theory-Practice Gap in Professional Sales

Throughout the history of sales research, scholars have identified a gap between theory and practice: the discrepancy that exists between what is being taught in classrooms and sales training, and the actual everyday practice of selling. This gap has been prevalent since the earliest work in selling and sales management. The extant sales literature provides organizations a number of theoretical approaches, frameworks and practices that claim to improve sales performance, in this changing sales landscape. However, while opinions abound, little scientific investigation has considered why the gaps persist.

Given this gap between scholarly sales theory and sales practice, this paper contributes by: 1 . confirming these gaps in several exemplar constructs, 2 . investigating potential antecedents for the gaps, and 3.exploring ideas for making theory and research more relevant and contextualized to help address these gaps. Our primary contribution comes from our qualitative investigation of what salespeople know theoretically, versus what they do practically, and what antecedents seem to underlie this gap. We believe this will shed light on how these gaps might be better addressed in the sales academy.

It is commonly considered that the main mission of scholarly research is to develop knowledge which translates into skills to advance the practice of that profession. As Herbert Simon wrote in the 1960s, management programs should "develop new knowledge that may be relevant to improving the operation of business" $(1967$, p. 5). However, several scholars have voiced concerns that the gap between theory and practice in various professional domains is widening (e.g. Anderson, Herriot and Hodgkinson 2001; Baldwinsdottir, Mitchell and Norreklit 2010; Rynes 2007). This theory-practice gap between formal knowledge produced by scholars 
and the applied knowledge practitioners need has actually been a persistent concern in the applied social sciences in general (Argyris and Schön 1974; Lupton 1983; Starbuck 2006), and in the business domain in particular (e.g. Shapiro, Kirkman and Courtney 2007).

So, the question of research impact on practice is central to all business research. Discussions about the lack of relevance to managerial practice are abundant in management research (e.g. Starkey and Madan 2001), and similar concerns have also been raised and addressed in several specialty fields, including marketing (e.g. Ankers and Brennan 2002).

Certainly, examples of tension in the business domain are substantial, and it is not our intent to review them all here, but as an illustration, we mention examples from the marketing capabilities and marketing strategy literatures. Kwaku (2005) and Vorhies, Orr and Bush (2011) note the challenges in rigidity versus dynamic capabilities in other domains. Kwaku (2005) explores these issues in the new product innovation space, while Vorhies and colleagues (2011) explore them as they relate to customer-focused marketing activities. Both works point to the need for continuous adaptability of firm capabilities to address the changing marketplace. Today's rapid change points to both a challenge for firms in adapting capabilities fast enough to keep up with their customer needs, as well as a need for academics to offer guidance on how to adapt, rather than give static solutions. Day elaborates on the reason for this gap as the inability to keep up with rapid change in the marketplace (e.g. Day 2011).

The marketing strategy literature also has concerns here (e.g. Day and Moorman 2013; Reibstein, Day and Wind 2009). Reibstein and colleagues (2009) note that the field has long been characterized by marketing research versus relevance issues, but that the divergence between academic research and practical concerns is increasing with the rapidly changing environment. They see that relevance is especially lacking in more strategic aspects, and that 
scholarly researchers increasingly start with their own interests, and not specific applications or practical problems. Reibstein and colleagues (2009) propose that academic researchers need to focus their orientation on practice and increase the relevance of their work. They note that academic institutions may need to change to support this orientation. This stream of work does identify the difficulties for practice itself in keeping up with the ever-changing environment.

In the field of sales, given these gaps also exist, it is important to explore research impact, relevance and implementation of scholarly sales research. Some concerns have been presented in the sales literature. For example, Töytäri and colleagues (2011) identified a gap between theory and application in value-based selling, showing that practical activities related to value-based selling remain sparse. In addition, the theory-practice gap in sales may be exacerbated by the continuously changing approach to sales, from early transactional to simple need satisfaction and relationship selling models, to a more complex collaborative and value co-creating model. There has been ongoing development of new theories, frameworks, strategies and processes for selling in recent years (e.g. Borg and Young 2014, Töytäri and Rajala 2015, Töytäri et al. 2011, Weitz 1981). Most recent approaches suggest that sales happen through exploring customer needs and finding suitable solutions together. Interaction becomes a core unit of analysis as value is created with customers in a dialogue. Several author teams call for rethinking the sales process (e.g. Barber and Tietje 2008, Dixon and Tanner 2012, Sheth and Sharma 2007), and we do not yet have evidence on how new value co-creating collaborative processes are received or implemented, or even if revision to the selling process is the appropriate approach.

So, there is clearly acceptance of the gap between theory and practice in sales. Should we as sales scholars be more concerned about how our research is impacting actual sales practice? If theory is the basis for understanding the reality of sales, it would seem reasonable to assume that 
what we tell managers and salespeople relates with what they experience in the field. It should also follow that if a gap is indeed identified between sales theory and sales practice, we need to reduce it. Otherwise, how can we determine what kind of knowledge and what kind of changes are actually going to help practitioners to improve selling results?

Given the on-going acknowledgement of this gap, our purpose is to confirm the existence of the gap today, and to uncover antecedent reasons for the gap. We seek perspective from marketing and management literatures on how sales scholars can work to close this gap to further the understanding of professional sales and better align with practicing managers. We do this by selecting certain constructs where gaps are prevalent in our dataset and use them as exemplars of gaps in sales practice in order to explore antecedents.

Following a brief introduction of three well-accepted gaps (listening, follow-up and adaptability), we introduce our method and findings. We base our study on an extensive qualitative research project on sales interaction conducted in Finland, with salespeople from six sales organizations, along with their customers. The dataset used for this study includes 39 indepth interviews, with additional data from video-recorded sales meetings and other interviews. We first establish that these three gaps are in fact still problematic in this context, and we explore the potential antecedents behind these gaps. Next, based on our findings, we look to other literatures, especially management and marketing, to propose specific strategies to aid in closing the gap between scholars and practitioners, as they stem from our findings.

\section{COMMONLY IDENTIFIED GAPS IN PRACTICE}

As discussed above, the gap between scholarly sales research findings and the practice of selling are prevalent and important. While the gap areas are numerous, we select only three of these gap areas to explore further. We chose these particular gaps because they emerged 
prominently in our study, identified both salespeople and customers, and because they are also all longstanding and well recognized in the literature. By choosing these prevalent gap areas to explore we have sufficient data and believe it increases the likelihood that we can identify antecedents that might shed light on other gaps, as they are theoretically representative.. Therefore, we specifically undertook consideration of theory-practice gaps in listening, followup and adapting by salespeople. Since each topic has been widely researched, both alone and as part of the sales process, we do not attempt a full literature review, but just a brief introduction of each.

Listening in sales is defined as "the cognitive process of actively sensing, interpreting, evaluating and responding to the verbal and non-verbal messages of present or potential customers (Castleberry and Shepherd 1999, p. 36).” Researchers find listening is important to develop buyer-seller relationships (Pryor et al. 2013), buyer trust and satisfaction (Aggarwal et al. 2005), retain customers (Sergio 2014), and to performance (Drollinger and Comer 2013).

Follow-up has been a part of the sales process from the earliest work in the area, and is important to complex selling and value co-creation. Ahearne, Jelinek and Jones (2007), developed a series of "salesperson service behaviors," similar to follow-up showing that these behaviors impacted customer satisfaction, trust, and customer share of the market.

For decades, the need for follow-up has been addressed as an area for improvement. For example, Maken (1990) suggested that better follow-through would lead to improved sales performance. Later, Williams, Everett and Rogul (2009) indicated that effective follow -up was more important than ever, given the changing selling environment. Most recently, we've seen evidence that follow-up in value-based selling is lacking. Töytäri and Rajala (2015) noted value assessment and monitoring were important parts of ongoing value-based selling relationships, 
and that in some cases, firms had good capability, but that it was clearly lacking in other cases. With the important role that follow-up can play, and evidence that it is often weak or lacking, this represents an important accepted gap for consideration.

Ever since Weitz (1981) first introduced a contingency framework in personal selling, along with the idea that adaptability is a key construct in sales effectiveness (and perhaps even before), the field has recognized the importance of adaptive selling. Adaptive Selling is "...the degree to which they alter their sales presentation across and during customer interactions in response to the perceived nature of the sales situation (Spiro and Weitz 1990, p. 61)." This construct has been extensively researched for a number of years (Goad and Jaramillo 2014), as adaptability seems to have high variability in actual execution. From its early roots, researchers knew that salespeople adapting was both important and not done well (e.g., Spiro and Weitz 1990). Despite this abundance of research and heavy emphasis on its importance, managers still bemoan the salespeople's ability to execute (Del Santo and Wollan 2013; Delvecchio et al 2004). With the importance and the variability in the sales force to adapt to customer needs, this appears to be another gap relevant to examine.

Additional extant literature on each area is identified in Table 1. We believe these exemplars will provide evidence of the theory-practice gap, and allow us to further explore antecedents to better understand ways to advance research and address gaps in the future.

Insert Table 1 about here

\section{METHODOLOGY}


In order to explore what kind of potential antecedent reasons can explain theory-practice gaps in sales, we used grounded theory. Grounded theory is a qualitative research method that aims at the development of theory of a phenomenon grounded in data from participants who have experienced that particular phenomenon (Glaser and Strauss 1967; Strauss and Corbin 1998). Grounded theory consists of systematic, yet flexible guidelines for collecting and analyzing qualitative data (Charmaz 2006) in order to obtain a deeper understanding of the studied phenomenon, and develop explanations and theory, rather than provide empirical generalizations. Grounded theory is one of the most widely used qualitative research methods across a wide range of disciplines and subjects (Bryant and Charmaz 2007; Locke 2002), and also becoming more prevalent in sales research (Geiger and Turley 2003; Johnson 2015).

Grounded theory is especially salient for examining potential antecedent reasons for theory-practice gaps for two reasons. First, the field of sales is currently evolving at an increasing rate, with the nature of customer sales interactions rapidly changing (Jones et al. 2005). So, although theory-practice gaps have been recognized in previous research, these developments might substantially influence how sales are conducted in practice, thus requiring us to reconsider our current understanding of them. Second, as we have demonstrated in our literature review, previous research has yet to investigate the main research question addressed in our study, namely the potential antecedent reasons behind these theory-practice gaps. Grounded theory is well suited for inductive theory development in these kinds of areas where theory is either still evolving or in need of updating (Locke 2001). In addition, grounded theory is also especially appropriate in providing deeper insights into the social dynamics of complex phenomena. Through a special focus and inclusion of different participant perspectives (Glaser and Strauss 1967), grounded theory is able to create a deeper picture of an emergent theory on 
social phenomena, such as why salespeople are not apply their theoretical knowledge in their everyday sales work.

The study reported in this paper draws its data from a larger research project on B-to-B sales in six companies in various fields of business services and business solutions in Finland. In this larger research project, multiple types of data were collected in both these sales organizations and in their customer organizations: in-depth interviews with both salespeople and customers, field observations in internal meetings and events, field observations in customer events, video-recordings of sales meetings between salespeople and customers, and various types of shorter interviews (e.g. interviews during fieldwork, interviews debriefing the video-recorded sales meetings, interviews following up on sales cases).

Following the grounded theory sampling recommendations from Glaser and Strauss (1967), the study moved from a broad initial sample to a more focused one in the later research stages. During the field stages of the research project, initial analysis was conducted upon a broad initial sample of 63 in-depth interviews with salespeople and 25 in-depth interviews with their customers ${ }^{1}$. This initial analysis revealed various issues related to problems in sales process and sales interaction, some of which related to how salespeople understood certain theoretical concepts, and how they were implementing other theoretical concepts, even when understood. As a result, in the initial analysis we identified several sales-related theory-practice gaps, including listening, follow-up, and adaptability. Following these initial insights, this study concentrates on a more focused data sample in order to analyze potential antecedents for these three theory-practice gaps.

\section{Sampling}


Compared to the field stages of the research project where a wide range of incidents were covered, for the data analysis for this study we followed the nonrandom sampling scheme of theoretical sampling (Strauss and Corbin 1998) focused on the theoretical relevance of the characteristics of the sample units in order to improve the completeness of the theoretical framework (Glaser 1998). Our sampling focused on specific seller-buyer dyads from our research project, where we had or could still collect sufficient empirical data to analyze the observed theory-practice gaps in more detail. In this, we considered that in order to gain sufficiently rich data to explore the reasons behind these gaps in detail, the seller-buyer dyads needed to have a) in-depth interviews with salespeople, b) in-depth interviews with customers who had done business with these specific salespeople, and c) access to additional data demonstrating a specific theory-practice gap in sales interaction. As a result, four seller-buyer dyads were chosen from three different sales organizations. These dyads provided empirical data to analyze three theory-practice gaps in more detail: listening, follow-up, and adaptability.

The dataset sampled for the analysis consists of 24 in-depth interviews from 16 employees of three sales organizations, and 15 in-depth interviews from nine employees of four of their customer organizations. The dataset is described in more detail in Table 2. Although the in-depth interviews form the main data used in the analysis, the inductions that were made in the analysis process are also based on understanding gained through other data sources; for example, understanding of sales calls was also based on video-recordings of sales meetings, interviews debriefing these sales meetings, or interviews following-up on the future developments of the sales cases. This additional data is also noted in Table 2.

Place Table 2 about here 
The contact to the sales companies was made through senior management, who encouraged people from selected business lines to participate. Interviews were held with business managers, sales managers, and sales representatives. These people worked under various job titles, but all had sales and/or sales management responsibilities within their organization. The variation in roles of the interviewees also provided a broad perspective on different levels of the sales organization. The interviewees from the customer side were first selected based on their participation in video-recorded sales meetings, after which a snowball sampling technique was used to identify other essential participants and key decision makers in the company's purchasing processes.

In the interviews, we used a thematic set of questions on various aspects of the sales/customer organization and seller-buyer interaction. This kind of interview protocol framed the topic of the interviews while allowing informants to guide the interview. The researchers focused on soliciting examples, clarifications, and related details as they spoke. All interviewees were assured of the confidentiality and anonymity of the interviews. The interviews were conducted face-to-face, audio-recorded, and transcribed verbatim, averaging around 59 minutes, representing more than 37 hours of audio recordings in total. The interview quotes presented in the findings sections come from interview transcriptions mostly in Finnish, translated to English by a professional translator.

\section{Data analysis}

The data analysis followed the general analytical principle of grounded theory, constant comparative method, which involves the simultaneous coding and analysis of data (Glaser and Strauss 1967). As explained by Locke (2001), "The constant comparative method is a procedure 
in which two activities, naming data fragments and comparing data incidents and names, occur in tandem" (p. 25). With constant comparison, all new data are compared to earlier data iteratively to enable adjustment of theoretical categories based on the ongoing analysis.

The data analysis involved both open and axial coding techniques (Strauss and Corbin 1998). First, in vivo codes (concepts based on the actual language used by the informants) were generated through an open coding process on various issues related to the three identified theory-practice gaps: listening, follow-up, and adaptability. These in vivo codes were then refined and grouped into higher-level concepts (first-order categories) through a process of comparing similarities and differences until the consistencies and constancies can be identified in the data (Locke 2002). In this phase, we investigated reasons explicitly identified by salespeople, reasons explicitly identified by customers, and contextual factors. In this constant comparison process, these reasons were also compared and contrasted against existing literature. The resulting higher-level concepts form the basis of the antecedents influencing the formation of theory-practice gaps in sales proposed in our findings. Finally, a process of axial coding was used to explore the relationships between and among the concepts, resulting in the categorization of the concept under different domains related to sales (second order themes) (Strauss and Corbin 1998).

\section{Research quality}

In order to ensure trustworthiness of our data and analytical rigor, we took a number of steps following Lincoln and Guba (1985). First, we ensured that our data management process was comprehensive and rigorous. We meticulously managed our data, including contact records, interview transcripts, video recordings, and field notes, as they were collected, using a computerbased qualitative data management program. Second, we followed a process of peer debriefing 
within the research team. We engaged team members not involved with the field research and data analysis to discussions on emerging patterns in the data. This served as a sounding board for evolving ideas, and questions about the data collection and analysis procedures. Finally, we verified our interpretations and the accuracy of the findings using a comprehensive and transparent member checking procedure (see Locke and Velamuri 2009). We shared our findings in six half-day workshops open to all research participants, one in each of the six companies that were involved in the research project. In each workshop, we presented our findings on a company-specific level, offering researcher portrayals and interpretations of observed events and practices. These portrayals and interpretations were anonymized in order to respect the confidentiality and anonymity of individual research participants. We asked workshop participants to offer their views on our interpretations of the data and the credibility of the findings, often in the form of interactive discussion in small groups. On a general level, our data interpretation and findings resonated well with workshop participants; on a detail level, our interpretation on specific events and practices were sometimes slightly revised based on workshop feedback.

\section{FINDINGS}

In this section, we present our findings on three identified theory-practice gaps: listening, follow-up, and adaptability.

\section{Listening Gap}

There is little question that most salespeople know they need to listen to customers or that a dialogue is better than a canned one-sided presentation (Castleberry et al. 1993). Our sales interviews show that salespeople indeed have this knowledge. For example, when prompted on 
what is important in selling, salespeople often pointed out the significance of listening to the customer:

The ability to listen is everything. The customer can usually, if you give them a chance, they can usually give you all the necessary information in just one meeting or one phone call. You just need the ability to find it. (Business Consultant)

It's listening to the customer. [...] they really start to bother me, the sellers who try to make me buy something. I'll tell you when I need something, I will contact you, and then I want you to listen to me, and sell me what I need. Listening to the customer, that is absolutely [the key]. (Specialist)

It is clear that salespeople see listening as a basic interpersonal skill than needs to be mastered in sales today. However, in our analysis, we found clear evidence of a theory-practice gap in listening; salespeople don't necessarily implement listening well. In our interviews, the customers told about problems in both listening to what the customer is saying, and in understanding what he is truly trying to express, and these problems were also visible in several video-recorded sales meetings.

Problems with listening often result in lack of common understanding. For example, one experienced director responsible for corporation's all operational facilities described his experiences in the following way:

It is the salesperson's skills, whether he understands what we are trying to say and whether he understands what we mean... it's very important that both parties can find certainty that we are talking about the same matter in the same way. Because sometimes it is a shame to realize... it simply means something different to us. (Head of Facilities)

Also, when salespeople fail to actively listen, customers are disenchanted, and various negative feelings may emerge. One managing director described his feelings in the following way:

It's sometimes frustrating to listen to the pitch about the product or the service when you know that it doesn't suit you... And they talk for an hour, and five minutes in you realize that it is not going to work, that you are not interested. (CEO) 
Multiple customers also made note that salespeople were not able to turn meetings into a dialogical two-way exchange of ideas. Customers feel that meetings often become monologues, instead of a constructive dialogue that would benefit both parties. A particularly vivid example of this was told us by one of our interviewees called Carsten. Carsten is an experienced CEO who typically meets hundreds of new potential partners every year. When meeting a sales representative of a company that was selling a technical production solution to enhance Carsten's service business, a nice dialogue emerged in the beginning. Excited by this promising start, Carsten told the sales representative extensively how his firm's service production worked, and about his own plans to develop it. After some specifying questions, the sales representative opened his laptop, and then a monologue ensued, completely ignoring the previous discussion. In that moment, Carsten told us that he felt that the sales representative did not listen to him, or even didn't understand the situation at all. Carsten became frustrated and ended the meeting in a hurry. So, it is evident that failing to listen to the customer may cause feelings of frustration, annoyance, and even anger, and that these feelings can diminish customers' perception of the trust and credibility of the sales organization, which in turn may lead to losing the sale.

As we analyzed our dataset, we were able to identify antecedents to the listening gap. These antecedents are detailed in Table 3, falling under three sales domains: salespeople, sales process, and sales management and organizational environment. Based on our analysis, salesperson's capability to listen is not only a question of the salesperson's personal skills. As an activity, listening is also affected and framed by the organizational support given to salespeople in the form of internal collaboration between teams and/or departments, freedom to be innovative on sales calls, as well as culture and sales management that promote not just outcomes but knowledge sharing and shared learning. 
Place Table 3 about here

\section{Follow-up Gap}

A core element of all sales processes, follow-up with customers, both during the sales process after the sale, is identified as an essential part of sales work by salespeople. For example, when describing his sales process, one business consultant described this part in the following way:

So we do little checks like, this is the stage we're in right now, and now we're doing this, this still needs to be done. (Business Consultant)

Salespeople also perceive the need to follow-up after sales. A key account manager explicitly told us how important it was to his business, noting that despite how good the service is, there are always some product failures or little problems that need to be quickly addressed. One of his colleagues told how he is systematically doing after-sale follow-up:

So I do try to do everything within the agreed time, with the agreed customers. I have a sort of a bible where I write this stuff. And occasionally I will stop and have a read, and it's like, oh yeah, this customer...that hasn't been done, so let's do it. (Sales Representative)

So, salespeople know that following up is part of the job, and that the task does not stop with a signature. However, in our interviews, customers repeatedly complained that salespeople did not follow-up in a timely or thorough manner, or even that they completely failed to followup. This was also evident in some of the debriefing interviews on video-recorded sales meetings. In other words, this basic activity was not implemented as often as could be expected, based on how salespeople described the practice; there is a theory-practice gap in follow-up.

Many of the customers expressed their sentiments on the lack of follow-up in a very frankly manner: 
It's not enough that they just send a Christmas card - I would maybe like them to get in touch after the sale, to ask whether the product or service has met the expectations and so forth, at least some kind of contact. (Sourcing Director)

In many cases, even small delays were identified and perceived relevant by customers. For example, a managing director says:

The initial meeting went quite well. We agreed that we would continue the discussion. There were a few matters that had to be checked, and the salesperson was going to send the minutes at some point on Friday. I don't really know... hmmm... it's now Monday evening and I haven't heard anything. (CEO).

Based on this small delay, the business buyer indicated concerns about the overall negotiation process and the credibility of the supplier to keep to its promises.

In many cases, lack of follow-up can even cost salespeople business they could have otherwise had. In following up on one of the sales meetings we had observed, one of our interviewees called Beth told us how she had a large customer despite the fact that the she initially knew her very well. She had brought along a support person to the sales meeting, and thought that he was following up on the customer; he thought she was. So while she got the initial business, there was finally no additional business to follow. As we interviewed the customer, an area director, she told us that the level of activity and delay in follow-up caused her to turn to a competing agency for their subsequent recruitment needs. So, the follow-up gap may not always affect the outcome of an individual sales call, but it influences the overall image and perception that the customer has about the company. The experiences and the perceived quality of the sales and service processes affect customer's willingness to buy from the company later on.

As we analyzed our dataset, we were able to identify antecedents to the follow-up gap. We identified six antecedents, detailed in Table 4, that fall under four sales domains: salespeople, sales interaction, sales process, and sales management and organizational 
environment. Based on our analysis, gaps in follow-up don't solely depend on unsystematic work habits, or delays in contacting customers. Problems with organizational culture and/or internal processes within the sales organization, such as valuing business or unclear roles between salespeople and others involved with the sales process, may lead to a situation where the salespeople don't have enough resources to handle all sales follow-up in an appropriate manner. Lack of resources like time can create problems, as can unexpected events (e.g. personnel changes) that require more work.

Place Table 4 about here

\section{Adaptability Gap}

Since Weitz, Sujan and Sujan (1981) introduced a framework for selling adaptability, defined in terms of altering the sales talk and benefits provided in the interaction, the concept has been relatively prevalent in sales. In our interviews, both salespeople and customers highlighted the need for adaptability as an essential part of successful selling. For example, many salespeople described their sales approach as being adapted according to the customer:

(We) rarely draw ready-made solutions from a hat, so it is, so (the customer) feels that this person somehow understands what you want and what you need, and then can even describe it to you in a suitable way. (Specialist)

Different customers have a different pulse. Say I go to the metal workers' union, they breathe at a different pace than, say, a luxury cars importer xyz or a medical technology firm xyz or somewhere; there, the pace is different. Your own way of working also has to, you kind of have to adapt to the customer's pace. (Business Consultant)

Adapting interaction requires salespeople to recognize the customer's current state of mind. Customer's level of interest can vary from meeting to meeting, depending on things like feelings, time constraints, and personal issues. An adaptive seller recognizes what the customer 
is able to process at a given time, and if necessary can decide to postpone critical discussions, as shown by this excerpt from an interview with a specialist:

So that you don't go and irritate the customer more than necessary. You should let it be and return to the issue later on (Specialist)

Based on our interviews, salespeople clearly know that they must adapt both the content and the style of interaction, according to customer needs. However, as with listening and followup, out interviews with the customers show that adapting is frequently not implemented in practice:

It's like a curse and a blessing. The sales pitches have been written already, so... Of course, every line of business has professional guys who can make it look like it's their own and they speak from the heart. But not when it is not. You can see that it's the same thing they sell to all companies. It's not... And then there's the need... I have often wondered why so little attention is paid to it, when it's probably the be-all and end-all of everything. (CEO)

So, although adapting seems to be recognized as an important phenomenon in selling, it is not clear that salespeople understand what it actually entails in practice: there is clearly a theorypractice gap in adaptability.

Sometimes salespeople seem to struggle with adaptability also because customers don't sufficiently tell them about their ideas or expectations, or when they feel that the customers expectations don't correspond to what the company or they as experts can offer. One of our interviewees, Alicia, told us about a particularly difficult sales call with a financial services customer. Alicia is a specialist within the business service that her company is selling. In this sales meeting, she felt that there was a complete mismatch between what she was telling about the service, and what the three clients from the customer side were thinking the service was about. Describing the meeting, she said:

I am not sure whether that was related to the company culture (...) they did not really tell what they were doing, or what they were aiming for, or what were their challenges. 
Alicia admitted she didn't know how to change her normal process to adapt to these clients, as she felt that they were expecting her to present clear strategic vision for their company without any initial discussions. As a result, creating a dialogue seemed problematic. Alicia felt she "couldn't get on the same page" with the clients, and couldn't adapt her vision to them. It seems then, that some of the reasons behind failed attempts to adapt to customers can also relate to the mismatch between expectations; for example, Alicia suspected that some of her problems could be explained by the fact that she didn't have the kind of expertise the clients were expecting her to have in relation to the business service she was selling.

As we analyzed our dataset, we identified altogether seven antecedents to the adaptability gap. These antecedents are detailed in Table 5, falling under four sales domains: salespeople, sales interaction, sales process, and sales management and organizational environment. Based on our analysis, sometimes salespeople might lack the authority and space required to adapt their performance, especially if companies are striving towards conformity in how they are perceived from the outside, or if salespeople are not sufficiently trained to be specialists in what they are selling. Alternatively, salespeople who are product experts could have a strong occupational identity that hinders willingness to adapt the solution to customer needs.

Place Table 5 about here

\section{Antecedents to Gaps}

We have now explored the antecedents identified for each of the theory-practice gaps separately. It is clearly visible that although the specific reasons that were identified for different gaps varied somewhat, we can clearly identify four general sales domains under which the 
different antecedent reasons fall: salespeople, sales interaction, sales process, and sales management and organizational environment. In other words, there are four clear domains related to sales from which the barriers for the successful implementation of sales theories arise. Under these general domains, we identified 15 different underlying antecedents. Figure 1 summarizes these 15 common underlying antecedents of gaps in theory-practice that emerged from our research, grouped under the four sales domains.

Insert Figure 1 about Here

It is worth noting that, while we chose to elaborate on findings for these three exemplars (listening, follow-up, and adaptability), we also saw examples of similar gaps in other areas of sales during our initial analysis. These included such areas as rapport building, relationship/trust development, and questioning. We believe that exploring these three robust exemplars of gaps provides insight to understanding antecedents to gaps, in general. The fact that most antecedent reasons seemed to arise from the four general domains related to sales supports the potential generalizability of our findings.

\section{DISCUSSION}

Our findings show that salespeople have a theoretical understanding of needed behaviors like listening, follow-up, and adapting. The interviewed salespeople saw each of these theorypractice gaps as important. Following the identification that salespeople were aware of what they needed to do, we found evidence that in many cases, despite the knowledge and import, the customer did not feel the salesperson was actually implementing the construct in practice. 
Finally, for each gap, we explored the reasons identifiable in our dataset and identified a number of antecedents that were summarized in Figure 1.

There are essentially two important paths that result in the actual doing of successful sales practice. First, the theoretical knowledge has to be disseminated to organizations and salespeople, and then the organizations need to assure implementation. Second, it is also necessary that academic theory be grounded in real world applicability, which in turn is contextualized (in other words, made understandable) for the individual salesperson's everyday work activities. Both pieces need to be in place to optimize sales practice.

The first question, then, is how to improve the processes of knowledge dissemination and implementation? The salespeople are aware that certain behaviors are important, but don't implement them. It would be unfair to simply blame the salesperson, given the pervasiveness of the gaps in our study, and literature more broadly. While there may be some aspects that can be controlled by the salesperson (i.e. some antecedents arising from salesperson behavior may fall under the salesperson control), but our findings indicate that turning to salesperson training, rewards, and management oversight for explanation is far too simplistic. Years of research and training related to each exemplar gap seem to have failed to remedy the problems. We must consider that, while some practical implications may be derived (and are discussed briefly later), we need to look at theory and knowledge development as well. It is quite plausible that the salesperson, and their managers, may not fully understand what is required of them because the academy hasn't done a good job in knowledge development. As discussed before, theories may not be grounded in reality or relevant to practice. They may not be contextualized, and not addressing the "how-to" of implementing knowledge. 
Secondly we argue, that for theory to inform practice in a meaningful way, theories must be made more relevant and more easily applicable. As used here, relevance focuses on the content and topic of the theory; that it ties to reality. Contextualization focuses on the level and description of the theory; that it can be directly applicable. Several of the antecedents we uncovered point to these ideas. In the domain of salespersons, both salespeople's attitudes and actions are included. Based on our findings, it seems that despite training, salespeople may stick to old habits and work practices if knowledge is not made contextualized and if organizational practices are not aligned to support the adoption of new habits/work practices. This notion of habit over training is well established elsewhere (e.g. Neal, Wood and Quinn 2006). In addition, salespeople might actually implement what they know (e.g. listening and follow-up) if other things would not get in their way (e.g. insufficient knowledge). As a result, theory can be made more relevant if it addresses how things relate to each other, not just effects of one specific variable. Finally, management needs to support sales rather than control. Control and rigidity were behind many antecedents. This also points to a need to assure the relevance of theories to assure management understands what is required of them. Overall, the types of antecedents point to the lack of relevance and contextualization in current theory and its constructs.

In addition, theoretical constructs often focus only on individual salesperson activity, as though the selling process occurs in isolation. However, our data suggests that successful sales interactions are highly dependent on organizational conditions and enablers. We identified several organizational enablers necessary for successful implementation, such as salesperson freedom and authority to act, as well as accessible social support. Moreover, our analysis identified that organizations need to create a working environment which promotes continuous learning through knowledge sharing and feedback. This kind of working environment enables 
constructs to be implemented successfully and developed over time. For theory to be relevant and contextualized, it needs to consider, not only the activity itself, but also conditions required from the surrounding organization.

Based on sales and marketing literature, as well as other disciplines, we identified two potential directions for academics that can improve academic work and potentially help to close some of these gaps through increased relevance and applicability of developed theories: grounded theorizing and contextualization. We will now discuss these in more detail in the following sections.

\section{Relevant Theory through Grounded Theorizing}

Across disciplines, the call for relevance exists. One concrete response to the concern for relevance is increased theorizing grounded in practical activities, such as the practice-based approaches to the study of strategy, accounting, or marketing. This approach was recently introduced to the sales academy (Geiger and Kelly 2014). Scholars have recently turned to practice-based approaches to analyzing business, basing their research on what Sandberg and Tsoukas (2011) call practical rationality theories in comparison to scientific rationality. These practice-based studies offer an alternative to traditional studies by looking at what is actually done in companies (i.e., the practice), rather than testing decontextualized theories of how something should be done. In various fields of business research, practice-based approaches are becoming increasingly widespread, from strategic management (strategy-as-practice, see Vaara and Whittington 2012) to accounting (accounting-as-practice, see Ahrens and Chapman 2006) and marketing (marketing-as-practice, see Skålen and Hackley 2011).

These approaches typically argue that by re-focusing research on the actions and interactions of practitioners, they bring an understanding of human action to the organizational 
phenomena under consideration (e.g. Jarzabkowski, Balogun and Seidl 2007). As such, practicebased analyses can be seen to reflect a broader concern to humanize research (Pettigrew et al. 2002). Following the lead by Geiger and Seamus (2014), this line of research in the field of sales may be one solution to bridge the gap between theory and practice. Sales-as-practice research is an approach that focuses our attention on how selling is actually done in practice, rather than creating decontextualized theories. As an example, the strategy-as-practice approach has enriched traditional research in four distinctive ways: 1. by broadening the scope of (basic) theories on which insights are drawn from (e.g. how do salespeople deal with unplanned events such as changes in contact persons as seen in the antecedents to follow-up?), 2. by broadening the scope of phenomena that research results explain (e.g. the unfolding of the sales process as it actually occurs or customer interaction antecedent), 3. by widening the types of organizations studies and making the research results more valid across different contexts (e.g. sales versus service roles and visions as seen in antecedents), and 4. by achieving a methodological shift, thus achieving a larger scope of accepted methods and methodological plurality (Vaara and Whittington 2012). It is our belief that that a similar development is desirable in the field of sales research to promote relevance.

The relevance of sales research depends, in part, of the extent to which practitioners' perspectives are included in the research process, and that the results are incorporated into activities that help companies to adapt to changing environments (see Mohrman, Gibson and Mohrman 2001). Although collaboration might not always be easy, Avenier and Cajaiba (2012) and others show that it is possible to develop research questions that meet both academic and practitioner interests. Orr and Bennett (2009) suggest that academic-practitioner interests may overlap despite different incentive structures. Thus, practitioners' voices should be added also to 
our academic discussions (Bartunek and Rynes 2014). The more we engage in communication and collaboration between academics and business practitioner, the more relevant and grounded our knowledge development will be.

\section{Applicable Theory through Contextualization}

It is widely recognized in the management literature that despite sufficient conceptual knowledge of what constitutes effective practice, managers may often lack the ability to apply that knowledge in context (Baldwin et al. 2010). In other words, companies have gaps between what they know, and how that knowledge translates into action. This diminishes the impact research has on managerial practice. As we know, and provide additional evidence for in this research, this applies to professional selling where sales knowledge does not always translate into practice.

Pfeffer and Sutton $(1999 ; 2000)$ state that most organizations do not suffer from ignorance; organizations have access to relevant knowledge and they know "what" to do. Instead, the main problem is that knowing "what" to do is not enough. In practice, they may ignore or act in contradiction to the known information. We need to turn knowledge into action. In doing this, knowing "what" is transformed into knowing "how," as the knowledge is situated and embedded in a particular context. According to an epistemology of practice, it is only in this situated activity where knowledge and knowing emerges (e.g. Cook and Brown 1999). Because knowing emerges through the activities in which people engage, it is always situated and contextual.

Researchers in other disciplines have suggested that this theory-practice gap stems from the fact that current theories do not resonate with practitioners due to their onto-epistemological underpinnings (Sandberg and Tsoukas 2011). In other words, research and practice produce 
distinct forms of knowledge. This is what the French sociologist Pierre Bourdieu (1990) meant when he said that the logic of practice is different from the logic of scientific theories: "practice has a logic which is not that of the logician" (p. 86). In this line of thought, Kondrat (1992) has argued that instead of beginning with definitions of knowledge "for" practice, we should start with questions like what knowledge does the practitioner (of an occupation or profession) use?, how does the practitioner obtain it?, what does the practitioner think?, how does the practitioner go about constructing action?, and how does a competent practitioner go about knowing "in" practice? These and similar questions have received limited attention, but they are crucial to understanding the relationship between theory and practice (Dreyfus and Dreyfus 1998). Adapting this alternative perspective in sales research could help to contextualize research findings and help close the theory-practice gap.

In developing scientific knowledge that would speak more directly to practitioners, academics also need to consider using a larger range of research designs and methodologies. Only an intimate connection with empirical reality permits the development of a testable, relevant, and valid theory (Glaser and Strauss 1967). This means that our research design, in terms of data to be collected, procedures of data collection, more detailed description in data, and type of analysis, should fit the current state of understanding and existing theory in the field ("methodological fit," see Edmondson and McManus 2007). Research approaches, such as case study or qualitative studies, generating more detailed, contextualized and rich data are especially appropriate in new topic areas with little prior work, when contradictory or paradoxical evidence exists or when the studied phenomena themselves are such that they cannot be studied as separated from the context in which they occur. Some phenomena require rich, contextualized data to be fully understood; especially dynamic research areas, such as value co-creation and 
solution customization may be examples of such. For some academics, qualitative field research is also a particular way of knowing the field, and thus not simply an empirical activity, but a theoretical one.

\section{THEORETICAL IMPLICATIONS}

There are a number of theoretical implications that scholars can consider in addressing the sales theory-practice gap. We have identified two main ways to address it based on literature. First, academics should pay more attention that knowledge produced is more relevant, through appropriate research questions and contextualized research designs, as discussed above. Also, academics should use more practice-based theorizing in order to produce knowledge that impacts actual sales practice. Both of these ways of reconsidering theory stem naturally from our findings regarding the antecedent reasons for our exemplar gaps.

The above discussion focuses on an overarching question of current sales theory development. We can identify some interesting specific findings that impact gaps for our exemplar constructs. Findings include identification of variables that should be considered in furthering our knowledge. Sales behaviors and attitudes can create barriers (e.g. fixed mindset, traditional processes) to the actual implementation of what the salesperson knows she should be doing. Researchers need to consider how the salesperson herself may be a barrier to successful implementation of good sales practice, and how this negative impact can be moderated. Similarly, when study focuses on salesperson behavior, researchers need to include context variables from the sales environment and firm processes, as well as sales management practice. This work provides some interesting insight on specific variables that might be included in the listening, follow-up, and adaptability research (and potentially other areas).

\section{MANAGERIAL IMPLICATIONS}


There are a number of potential practical implications that managers can consider in addressing the theory-practice gap, including leadership, culture, organizational support, and coaching. In addition, training programs need better follow-through and new pedagogy. These practical implications are discussed below. While we believe some immediate issues may be addressed by management, we also feel that this is a more transitory solution, and that ultimately it falls to the academy to make the work more relevant and contextualized.

First, strong implementation requires strong leadership, without controlling. Our results seem to point to the fact that, if salespeople are to implement, they need to know what is expected, when it is expected, and the consequences of achieving or not achieving the expectations (Ingram et al. 2005). This clarity has to be accompanied by leadership supportiveness and a commitment to continuous learning. One antecedent to theory-practice gaps was sales management that over-relied on outcome measures. Managers need to role model good sales practices that may not be implemented well right now, and focus on process to supplement outcomes.

Another potential area for practitioners to look is the culture of the sales organization. Organizations know that the sales culture is important to success (Ridnour, Laask and Shepherd 2001), but need to make sure that the culture is one that supports implementation of the desired behaviors required by the theoretical knowledge. A culture that focuses on competitiveness will not be likely to spawn collaboration. A culture that is autocratic doesn't breed good dialoging. Sales managers need to take a look at culture and existing organizational structures, perhaps with a good sales culture diagnosis, and make sure that it fits with what they want to accomplish. This was a contextual factor that needs further investigation, but may be influenced by sales strategy in the short run. 
Although training typically addresses many issues related to process, , much sales training suffers from a lack of follow through, as we saw in our findings. Managers may wish to take a look to see if better training follow-through would help to eliminate the theory-practice gap in some aspects of their sales force. One day of training is not enough to establish strong new habits or routines, in particular those needed to overcome longstanding habits. Systems for further practice, evaluation and feedback need to be developed. Managers should also consider including new elements in sales training that promote implementation and application (Silberman and Auerbach 2006). For example, the use of interactive, theatrical drama-based methods in training creates experiential learning that enhances salespersons' capabilities to apply new skills in practice (e.g., Antal 2014).

And finally, busy managers, especially for experienced salespeople, may overlook coaching even if it can be more efficient than more traditional forms of training. Our findings seemed to demonstrate that coaching and other support was deficient. Effective sales managers realize that placing a high priority on coaching will drive better implementation, more consistently (Shannahan, Bush and Shannahan 2013). While this list is not exhaustive, there are some ways to focus managerial attention on helping salespeople translate what they know to what they do.

\section{CONCLUSION}

In looking at the context of our data, we first show that specific well-known examples of theory-practice gaps (in listening, follow-up, and adaptability) do in fact exist. We explore the potential antecedent reasons that emerge from our data. These antecedents stem primarily from the domains of salespeople, sales interaction, sales process, and sales management and organizational environment. Next, we propose specific measures to help academic researchers to 
address these gaps, such as making research more relevant (including using practice-based approaches), and better contextualizing work in the area. We believe our suggestions can help to redirect future efforts to assure that theory development is relevant, contextualized, and useful in informing future professional selling practice. The paper contributes by looking beyond the identification of theory-practice gaps, to their underlying reasons. Change is needed to evolve sales research for future success. 
${ }^{1}$ These 88 in-depth interviews were conducted in six sales organizations and eleven customer organizations. The interviews included salespeople from different levels within the organizations (34.9\% managerial level, 65.1\% operational level). Customer interviews included 18,2\% professional buyers (e.g. sourcing managers) and 81,8\% business buyers (e.g. CEOs, different types of business managers, production managers). Interviewees' work experience varied from 5 up to 40 years, most of them having 10-20 years of experience. All interviews were conducted face-to-face, audio-recorded, and transcribed verbatim. These interviews averaged around 65 minutes, representing more than 90 hours of audio recordings in total. 


\section{REFERENCES}

Aggarwal, Praveen, Stephen B. Castleberry, C. David Shepherd, and Rick Ridnour (2005), "Salesperson Empathy and Listening: Impact on Relationship Outcomes," Journal of Marketing Theory \& Practice, 13(3), 16-31.

Ahearne, Michael, Ronald Jelinek, and Eli Jones (2007), "Examining the Effect of Salesperson Service Behavior in a Competitive Context," Journal of the Academy of Marketing Science, 35(4), 603-616.

Ahrens, Thomas, and Christopher S. Chapman (2006), "Doing Qualitative Field Research in Management Accounting: Positioning Data to Contribute to Theory," Accounting, Organizations and Society, 31(8), 819-41.

Anderson, Neil, Peter Herriot, and Gerard P. Hodgkinson (2001), "The Practitioner-Researcher Divide in Industrial, Work and Organizational (IWO) Psychology: Where Are We Now, and Where Do We Go From Here?" Journal of Occupational \& Organizational Psychology, 74(4), 391-411.

Ankers, Paul, and Ross Brennan (2002), "Managerial Relevance in Academic Research: An Exploratory Study," Marketing Intelligence \& Planning, 20(1), 15-21.

Antal, Ariane Berthoin (2014), "When Arts Enter Organizational Spaces: Implications for Organizational Learning", in: Learning Organizations: Extending the Field, Ariane Berthoin Antal, Peter Meusburger, and Laura Suarsana, eds., Dordrecht: Springer, 177201.

Argyris, Chris, and Donald A. Schön (1974), Theory in Practice: Increasing Professional Effectiveness, San Francisco, CA: Jossey-Bass.

Avenier, Marie Jose, and Aura Parmentier Cajaiba (2012), "The Dialogical Model: Developing Academic Knowledge For and From Practice", European Management Review, 9(4), 199-212.

Baldwinsdottir, Gurun, Falconer Mitchell, and Hanne Norreklit (2010), "Issues in the Relationship between Theory and Practice in Management Accounting," Management Accounting Research, 21(2), 79-82.

Barber, Clifford S., and Brian C. Tietje (2008), "A Research Agenda for Value Stream Mapping the Sales Process," Journal of Personal Selling and Sales Management, 28(2), 155-65.

Bartunek, Jean Marie, and Sara Lynn Rynes (2014), "Academics and Practitioners Are Alike and Unlike: The Paradoxes of Academic-Practitioner Relationships," Journal of Management, 40(5), 1181-201.

Borg, Susanne Wiatr, and Louise Young (2014), "Continuing the Evolution of the Selling 
Process: A Multi-level Perspective," Industrial Marketing Management, 43(4), 543-52.

Bourdieu, Pierre (1990), The Logic of Practice, Stanford, CA: Stanford University Press.

Bryant, Antony, and Kathy Charmaz (2007), "Introduction. Grounded Theory Research: Methods and Practices", in: The Sage Handbook of Grounded Theory, Anthony Bryant and Kathy Charmaz, eds., Thousand Oaks, CA: Sage, 1-28.

Castleberry, Stephen, and C. David Shepherd (1999), "Effective Interpersonal Listening in the Personal Selling Environment: Conceptualization," Journal of Marketing Theory \& Practice, 7(1), 30-39.

Charmaz, Kathy (2006), Constructing Grounded Theory: A Practical Guide through Qualitative Analysis, London: Sage.

Cook, Scott D. N., John Seely Brown (1999), "Bridging Epistemologies: The Generative Dance Between Organizational Knowledge and Organizational Knowing," Organization Science, 10(4), 381-400.

Day, George, and Christine Moorman (2013), "Regaining Customer Relevance: The Outside-In Turnaround," Strategy and Leadership, 41(4), 17-23.

Del Santo, John, and Robert Wollan (2013), “Adapting to Change," Best's Review, 114(4), 5960.

Delvecchio, Susan, James Zemanek, Roger Mcintyre, and Reid Claxton (2004), "Updating the Adaptive Selling Behaviours: Tactics to Keep and Tactics to Discard," Journal of Marketing Management, 20(7/8), 859-75.

Dixon, Andrea L., and John (Jeff) F. Tanner, Jr. (2012), "Transforming Selling: Why It Is Time to Think Different About Sales Research," Journal of Personal Selling and Sales Management, 32(1), 9-13.

Dreyfus, Hubert L., and Stuart E. Dreyfus (1998), "Frictionless Forecasting is a Fiction," in: The Necessity of Friction, Nordal Åkerman, ed., Boulder, CO: Westview Press, 267-89.

Drollinger, Tanya, and Lucette B. Comer (2013), "Salesperson's Listening Ability as an Antecedent to Relationship Selling," Journal of Business \& Industrial Marketing, 28(1), 50-59.

Edmondson, Amy C., and Stacy E. McManus (2007), Methodological Fit in Management Field Research," Academy of Management Review, 32 (4), 1155-79.

Geiger, Susi, and Kelly Seamus (2014), "Sales-as-Practice: An Introduction and Methodological Outline," Journal of Personal Selling and Sales Management, 34(3), 223-31. 
Geiger, Susi, and Darach Turley (2003), "Grounded Theory in Sales research: An Investigation of Salespeople's Client relationships”, Journal of Business \& Industrial Marketing, 18(6/7), 580-94.

Glaser, Barney G. (1998), Doing Grounded Theory: Issues and Discussions. Mill Valley, CA: Sociology Press.

Glaser, Barney G., and Anselm L. Strauss (1967), The Discovery of Grounded Theory: Strategies for Qualitative Research. New York: Aldine de Griyter.

Goad, Emily A., and Fernando Jaramillo (2014)," The Good, the Bad and the Effective: A MetaAnalytic Examination of Selling Orientation and Customer Orientation on Sales Performance," Journal of Personal Selling and Sales Management, 34(4), 285-301.

Ingram, Thomas N., Raymond W. LaForge, William B. Locander, Scott B. MacKenzie, and Philip M. Podsakoff (2005), "New Directions in Sales Leadership Research," Journal of Personal Selling and Sales Management, 25(2), 137-54.

Jarzabkowski, Paula, Julia Balogun, and David Seidl (2007), "Strategizing: The Challenges of a Practice Perspective," Human Relations, 60(1), 5-27.

Johnson, Jeff S. (2015), "Qualitative Sales Research: An Exposition of Grounded Theory," Journal of Personal Selling \& Sales Management, 35(3), 262-73.

Jones, Eli, Steven P. Brown, Andris A. Zoltners, and Barton A. Weitz (2005), "The Changing Environment of Selling and Sales Management", Journal of Personal Selling \& Sales Management, 25(2): 105-11.

Kondrat, Mary Ellen (1992), "Reclaiming the Practical: Formal and Substantive Rationality in Social Work Practice," Social Service Review, 166(2), 237-55.

Kwaku, Atuahene-Gima (2005), "Resolving the Capability-Rigidity Paradox in New Product Innovation," Journal of Marketing, 69(4), 69-83.

Lincoln, Yvonna S., and Egon G. Guba (1985), Naturalistic Inquiry, Beverly Hills, CA: Sage.

Locke, Karen (2001), Grounded Theory in Management Research, London: Sage.

Locke, Karen (2002), “The Grounded Theory Approach to Qualitative Research”, in: Fritz Drasgow and Neal Schmitt, eds., Measuring and Analyzing Behavior in Organizations: Advances in Measurement and Data Analysis, San Francisco, CA: Jossey-Bass, 17-43.

Locke, Karen, and S. Ramakhrishna Velamuri (2009), "The Design of the Member Review: Showing What to Organization Members and Why", Organizational Research Methods, 12(3), 488-509. 
Lupton, Tom (1983), Management and the Social Sciences, 2nd ed., Harmondsworth, UK: Penguin.

Mohrman, Susan Albers, Cristina B. Gibson, and Allan M. Mohrman, Jr. (2001), "Doing Research That is Useful to Practice: A Model and Empirical Exploration," Academy of Management Journal, 44(2), 357-75.

Neal, David T., Wendy Wood, and Jeffrey M. Quinn (2006), "Habits-A Repeat Performance," Current Directions in Psychological Science, 15(4), 198-202.

Orr, Kevin, and Mike Bennett (2009), "Reflexivity in the Co-Production of AcademicPractitioner Research," Qualitative Research in Organizations and Management, 4(1), 85-102.

Pfeffer, Jeffrey, and Robert I. Sutton (1999), "Knowing 'What' to Do is Not Enough: Turning Knowledge into Action," California Management Review, 42(1), 83-108.

Pfeffer, Jeffrey, and Robert I. Sutton (2000), The Knowing-Doing Gap: How Smart Companies Turn Knowledge into Action, Boston, MA: Harvard Business School Press.

Pettigrew, Andrew, Howard Thomas, and Richard Whittington (2002), "Strategic Management: The Strengths and Limitations of a Field," in: The Handbook of Strategy and Management, Andrew Pettigrew, Howard Thomas, and Richard Whittington, eds., London: Sage, 3-30.

Pryor, Susie, Avinash Malshe, and Kyle Paradise (2013), "Salesperson Listening in the Extended Sales Relationship: An Exploration of Cognitive, Affective, and Temporal Dimensions," Journal of Personal Selling \& Sales Management, 33(2), 185-96.

Reibstein, David J., George Day, and Jerry Wind (2009), “Guest Editorial: Is Marketing Academia Losing Its Way?” Journal of Marketing, 73(4), 1-3.

Ridnour, Rick E., Felicia G. Lassk, and C. David Shepherd (2001), “An Exploratory Assessment of Sales Culture Variables: Strategic Implications within the Banking Industry," Journal of Personal Selling and Sales Management, 21(3), 247-254.

Román, Sergio (2014), "Salesperson's Listening in Buyer-Seller Service Relationships,” The Service Industries Journal, 34(7), 630-44.

Rynes, Sara L. (2007), “Editor's Foreword: Tackling the 'Great Divide' Between Research Production and Dissemination in Human Resource Management," Academy of Management Journal, 50(5), 985-86.

Sandberg, Jörgen, and Haridimos Tsoukas (2011), "Grasping the Logic of Practice: Theorizing Through Practical Rationality," Academy of Management Review, 36(2), 338-60. 
Shannahan, Kirby L.J., Alan J. Bush, and Rachelle J. Shannahan (2013) “Are Your Salespeople Coachable? How Salesperson Coachability, Trait Competitiveness, and Transformational Leadership Enhance Sales Performance," Journal of the Academy of Marketing Science, 41(1), 40-54.

Shapiro, Debra L., Bradley L. Kirkman, and Hugh G. Courtney (2007), "Perceived Causes and Solutions of the Translation Problem in Management Research," Academy of Management Journal, 50(2), 249-66.

Sheth, Jagdish N., and Arun Sharma (2007), "The Impact of the Product to Service Shift in Industrial Markets and the Evolution of the Sales Organization," Industrial Marketing Management, 37(3), 260-69.

Simon, Herbert (1967), "The Business School: A Problem in Organizational Design," Journal of Management Studies, 4(1), 1-16.

Silberman, Melvin L., and Carol Auerbach (2006), Active Training: A Handbook of Techniques, Designs, Case Examples, and Tips, San Francisco, CA: Pfeiffer.

Skålen, Per, and Chris Hackley (2011), "Marketing-as-Practice. Introduction to the Special Issue," Scandanavian Journal of Marketing, 27(2), 189-95.

Spiro, Rosann L., and Barton A. Weitz (1990), "Adaptive Selling: Conceptualization, Measurement, and Nomological Validity," Journal of Marketing Research, 27(1), 61-69.

Starbuck, William H. (2006), The Production of Knowledge: The Challenge of Social Science Research, Oxford: Oxford University Press.

Starkey, Ken, and Paula Madan (2001), "Bridging the Relevance Gap: Aligning Stakeholders in the Future of Management Research," British Journal of Management, 12(Special Issue), S3-S26.

Strauss, Anselm L., and Juliet M. Corbin (1998), Basics of Qualitative Research: Techniques and Procedures for Developing Grounded Theory, 2nd ed., Thousand Oaks, CA: Sage.

Töytäri, Pekka, Thomas Brashear Alejandro, Petri Parvinen, Ilmari Ollila, and Nora Rosendahl (2011), "Bridging the Theory to Application Gap in Value-Based Selling," Journal of Business and Industrial Marketing, 26(7), 493-502.

Töytäri, Pekka, and Risto Rajala (2015); "Value-Based Selling: An Organizational Capability Perspective," Industrial Marketing Management, 45 (2), 101-12.

Vaara, Eero, and Richardt Whittington (2012), "Strategy-as-Practice: Taking Social Practices Seriously," The Academy of Management Annals, 6(1), 285-336.

Vorhies, Douglas, Linda Orr, and Victoria Bush (2011), "Improving customer-focused marketing 
capabilities and firm financial performance via marketing exploration and exploitation," Journal of the Academy of Marketing Science, 39(5), 736-56.

Weitz, Baron (1981), "Effectiveness in Sales Interactions: A Contingency Framework," Journal of Marketing, 45(1), 85-103.

Weitz, Barton A., Harish Sujan and Mita Sujan (1986), "Knowledge, Motivation, and Adaptive Behavior: A Framework for Improving Selling Effectiveness," Journal of Marketing, 50(4), 174-91.

Williams, J.D., Robert Everett, and Elizabeth Rogol (2009), "Will the Human Factors of Relationship Selling Survive in the Twenty-First Century?" International Journal of Commerce and Management, 19(2), 158-75. 


\section{Table 1}

\section{Findings from Extant Literature}

\begin{tabular}{|c|c|}
\hline Source & Perspective \\
\hline \multicolumn{2}{|c|}{ Gap 1: Listening } \\
\hline $\begin{array}{l}\text { Román (2014), "Salesperson's listening in buyer-seller service } \\
\text { relationships," SIJ, } 34 \text { (7), 630-644. }\end{array}$ & $\begin{array}{l}\text { Control systems impact salesperson listening and } \\
\text { influence of listening on customer retention. }\end{array}$ \\
\hline $\begin{array}{l}\text { Román, Ruiz, and Munuera (2005), "The Influence of the } \\
\text { compensation system and personal variables on a salesperson's } \\
\text { effective listening behavior," JMM, 21, 205-230. }\end{array}$ & $\begin{array}{l}\text { Salesperson listening effectiveness is affected by several } \\
\text { variables including method of compensation, ability to use } \\
\text { customer knowledge, intrinsic motivation, gender, } \\
\text { education and experience. }\end{array}$ \\
\hline $\begin{array}{l}\text { Pryor, Malshe, and Paradise (2003), "Saleperson listening in } \\
\text { the extended sales relationship: An exploration of congnitive, } \\
\text { affective, and temporal dimensions," JPSSM, 23(2), 185-196. }\end{array}$ & $\begin{array}{l}\text { Listening has both cognitive and affective characteristics. } \\
\text { There is a link between the salesperson's listening and the } \\
\text { impressions of affective and cognitive empathy created } \\
\text { and maintained over the course of sales interactions, } \\
\text { which may impact relationship development. }\end{array}$ \\
\hline $\begin{array}{l}\text { Comer, and Drollinger (1999), "Active empathetic listening } \\
\text { and selling success: A conceptual framework," JPSSM, } 19 \text { (1), } \\
20-29 .\end{array}$ & $\begin{array}{l}\text { The most effective level of listening combines empathy } \\
\text { with the techniques of active listening. Active, } \\
\text { empathetic listening can facilitate personal selling. }\end{array}$ \\
\hline $\begin{array}{l}\text { Ramsey and Sohi (1997), "Listening to your customers: The } \\
\text { impact of perceived salesperson listening behavior on } \\
\text { relationship outcomes," JAMS, } 25 \text { (2), 127-137. }\end{array}$ & $\begin{array}{l}\text { Listening is a higher-order construct composed of three } \\
\text { dimensions: (a) sensing, (b) evaluating, and (c) } \\
\text { responding. }\end{array}$ \\
\hline \multicolumn{2}{|c|}{ Gap 2: Follow-Up } \\
\hline $\begin{array}{l}\text { Sabnis, Chatterjee, Grewal, and Lillien (2013), "The sales lead } \\
\text { black hole: On sales reps' follow-up of marketing leads," JM, } \\
77 \text { (Jan.), 52-67. }\end{array}$ & $\begin{array}{l}\text { With experience, lead follow-up volume decreases but } \\
\text { quality increases. }\end{array}$ \\
\hline $\begin{array}{l}\text { Moore, Raymond, and Hopkins (2011), "A comparison of B2B } \\
\text { and B2C sales profession's utilization of social media } \\
\text { technologies," SMA Proceedings, 221-222. }\end{array}$ & $\begin{array}{l}\text { Results show that social media tools are used most often } \\
\text { during prospecting and follow-up after a sale. }\end{array}$ \\
\hline $\begin{array}{l}\text { Smith, Gopalakrishna, and Chatterjee (2006), "A three-stage } \\
\text { model of integrated marketing communications at the } \\
\text { marketing-sales interface," JMR, 43, 564-579. }\end{array}$ & $\begin{array}{l}\text { Lead volume could hurt downstream sales because of } \\
\text { delays in sales follow-up when sales force time is } \\
\text { redirected here. }\end{array}$ \\
\hline
\end{tabular}




\begin{tabular}{|l|l|}
\hline $\begin{array}{l}\text { Dublinsky (1981), “A factor analytic study of the personal } \\
\text { selling process," JPSSM, 1, 26-33. }\end{array}$ & Follow-up identified as an essential stage in the process. \\
\hline \multicolumn{1}{|c|}{ Gap 3: Adaptability } \\
\hline $\begin{array}{l}\text { Locander, Mulki, and Weinberg (2014), "How do salespeople } \\
\text { make decisions? The role of emotions and deliberation on } \\
\text { adaptive selling, and the moderating role of intuition," } \\
\text { Psychology \& Marketing, 31 (6), 387-403. }\end{array}$ & $\begin{array}{l}\text { Intuition moderates the significant role that regulation of } \\
\text { emotions and deliberation play in encouraging adaptive } \\
\text { selling behavior. }\end{array}$ \\
\hline $\begin{array}{l}\text { Friend, Curasi, Boles, and Bellenger (2014) "Why are you } \\
\text { really losing sales opportunities? A buyers' perspective on the } \\
\text { determinants of key account sales failures," IMM, 43 (7), } \\
\text { 1124-35. }\end{array}$ & $\begin{array}{l}\text { Adaptability has multiple drivers and is often a common } \\
\text { cause of failure for key account managers. }\end{array}$ \\
\hline $\begin{array}{l}\text { Verbeke, Dietz, and Verwaal (2011), "Driv- } \\
\text { ers of sales performance: A contemporary meta-analysis," } \\
\text { JAMS, 39, 407-428. }\end{array}$ & $\begin{array}{l}\text { Adaptability is one of the five most critical components of } \\
\text { salesperson performance. }\end{array}$ \\
\hline $\begin{array}{l}\text { Ahearne, Jones, Rapp, and Mathieu (2008), "High touch } \\
\text { through high tech: The impact of salesperson technology usage } \\
\text { on sales performance via mediating mechanisms," MS, 54(4), } \\
\text { 671-685. }\end{array}$ & IT Use can improve salesperson's adaptability \\
\hline $\begin{array}{l}\text { Bruce D. Keillor, R. Stephen Parker (1999) "Sales Force } \\
\text { Performance Satisfaction and Aspects of Relational Selling," } \\
\text { JMTP, 99, 101-115. }\end{array}$ & $\begin{array}{l}\text { Adaptability was not significantly related to the } \\
\text { salesperson's satisfaction with their performance. }\end{array}$ \\
\hline $\begin{array}{l}\text { Porter, Inks, and Lawrence (2000), "Cognitive Complexity and } \\
\text { Salersperson Adaptability," JPSSM, 20 (1), 15-21. }\end{array}$ & $\begin{array}{l}\text { Suggests an elaborate knowledge structure will influence } \\
\text { salesperson's tendency to practice adaptive selling. }\end{array}$ \\
\hline
\end{tabular}




\section{Table 2}

\section{Data Set Information}

\begin{tabular}{|c|c|c|c|c|c|c|c|c|c|}
\hline $\mathbf{N}$ & Role & Industry & Size & Level & Job title & Sex & $\begin{array}{l}\text { Experi- } \\
\text { ence* }\end{array}$ & $\begin{array}{l}\text { Inter- } \\
\text { views }\end{array}$ & Additional data \\
\hline 1 & Sales & Business services & SME & Junior & Specialist & $\mathrm{F}$ & Low & 1 & \\
\hline 2 & Sales & Business services & SME & Junior & Specialist & $\mathrm{F}$ & Low & 1 & $\begin{array}{l}\text { Participating in } 1 \text { video-recorded } \\
\text { sales meeting, } 1 \text { debriefing } \\
\text { interview }\end{array}$ \\
\hline 3 & Sales & Business services & SME & Junior & Specialist & $\mathrm{M}$ & Low & 1 & \\
\hline 4 & Sales & Business services & SME & Junior & Specialist & $\mathrm{F}$ & Medium & 1 & $\begin{array}{l}\text { Participating in } 1 \text { video-recorded } \\
\text { sales meeting, } 1 \text { debriefing } \\
\text { interview }\end{array}$ \\
\hline 5 & Sales & Business services & SME & Junior & Specialist & $\mathrm{F}$ & High & 1 & \\
\hline 6 & Sales & Business services & SME & Senior & $\mathrm{CEO}$ & $\mathrm{F}$ & Medium & 1 & \\
\hline 7 & Sales & ICT solutions & Large & Junior & Sales Representative & M & Medium & 2 & $\begin{array}{l}\text { Participating in } 2 \text { video-recorded } \\
\text { sales meetings, } 2 \text { debriefing } \\
\text { interviews }\end{array}$ \\
\hline 8 & Sales & ICT solutions & Large & Junior & Sales Representative & $\mathrm{M}$ & Medium & 2 & \\
\hline 9 & Sales & ICT solutions & Large & Junior & Sales Representative & $\mathrm{M}$ & Medium & 2 & $\begin{array}{l}\text { Participating in } 1 \text { video-recorded } \\
\text { sales meeting, } 1 \text { debriefing } \\
\text { interview }\end{array}$ \\
\hline 10 & Sales & ICT solutions & Large & Junior & Business Consultant & $\mathrm{F}$ & Medium & 2 & \\
\hline 11 & Sales & ICT solutions & Large & Middle & Key Account Manager & $\mathrm{M}$ & High & 2 & \\
\hline 12 & Sales & ICT solutions & Large & Middle & Sales Manager & M & High & 2 & \\
\hline 13 & Sales & ICT solutions & Large & Senior & $\begin{array}{l}\text { Director of Sales and } \\
\text { Marketing }\end{array}$ & M & High & 1 & \\
\hline 14 & Sales & $\begin{array}{l}\text { Staffing and } \\
\text { recruitment services }\end{array}$ & Large & Middle & Sales Manager & $\mathrm{F}$ & High & 2 & $\begin{array}{l}\text { Participating in } 1 \text { video-recorded } \\
\text { sales meetings, } 1 \text { follow-up } \\
\text { interview }\end{array}$ \\
\hline 15 & Sales & $\begin{array}{l}\text { Staffing and } \\
\text { recruitment services }\end{array}$ & Large & Middle & Business Area Manager & M & Medium & 2 & \\
\hline
\end{tabular}




\begin{tabular}{|l|l|l|l|l|l|l|l|l|l|}
\hline 16 & Sales & $\begin{array}{l}\text { Staffing and } \\
\text { recruitment services }\end{array}$ & Large & Senior & Director of Sales & M & High & 1 & \\
\hline 17 & Customer & ICT services & Large & Middle & $\begin{array}{l}\text { Corporate } \\
\text { Responsibility Manager }\end{array}$ & F & Medium & 1 & $\begin{array}{l}\text { Participating in 1 video-recorded } \\
\text { sales meeting, 1 debriefing } \\
\text { interview }\end{array}$ \\
\hline 18 & Customer & Research services & SME & Junior & Development Manager & M & High & 1 & $\begin{array}{l}\text { Participating in 1 video-recorded } \\
\text { sales meeting, 1 debriefing } \\
\text { interview }\end{array}$ \\
\hline 19 & Customer & Retail & Large & Middle & $\begin{array}{l}\text { Customer Relationship } \\
\text { Manager }\end{array}$ & M & Medium & 2 & \\
\hline 20 & Customer & Retail & Large & Middle & Purchasing Manager & M & Junior & 2 & \\
\hline 21 & Customer & Retail & Large & Senior & Area Director & F & Medium & 2 & $\begin{array}{l}\text { Participating in 1 video-recorded } \\
\text { sales meeting }\end{array}$ \\
\hline 22 & Customer & $\begin{array}{l}\text { Transportation } \\
\text { services }\end{array}$ & Large & Junior & Advisor & M & Medium & 2 & $\begin{array}{l}\text { Participating in 1 video-recorded } \\
\text { sales meeting, 1 debriefing } \\
\text { interview }\end{array}$ \\
\hline 23 & Customer & $\begin{array}{l}\text { Transportation } \\
\text { services }\end{array}$ & Large & Senior & CEO & M & High & 2 & $\begin{array}{l}\text { Participating in 1 video-recorded } \\
\text { sales meeting, 1 debriefing } \\
\text { interview }\end{array}$ \\
\hline 24 & Customer & $\begin{array}{l}\text { Transportation } \\
\text { services }\end{array}$ & Large & Senior & Head of Facilities & M & High & 1 & \\
\hline 25 & Customer & $\begin{array}{l}\text { Transportation } \\
\text { services }\end{array}$ & Large & Senior & Sourcing Director & F & High & 2 & \\
\hline
\end{tabular}

* Experience level: Low experience 0-3 years, medium experience 4-9 years, high experience over 10 years. 
Table 3

Antecedents Related to the Formation of a Listening Gap

\begin{tabular}{|c|c|c|c|}
\hline Domain & Antecedent & Explanation & Illustrative quote \\
\hline \multirow[t]{3}{*}{ Salespeople } & $\begin{array}{l}\text { Insufficient or erroneous } \\
\text { customer knowledge }\end{array}$ & $\begin{array}{l}\text { Salespeople have insufficient or erroneous } \\
\text { knowledge about the customer's context } \\
\text { (company, business, market etc.). } \\
\text { Insufficient knowledge can also result from } \\
\text { insufficient preparation. For the customer, it } \\
\text { can feel like the salesperson is speaking a } \\
\text { different language than they are. }\end{array}$ & $\begin{array}{l}\text { They probably know in great detail, which } \\
\text { way the button goes in any given situation. } \\
\text { But to be able to better look at it from this } \\
\text { side of the table, so to speak. To put } \\
\text { themselves in the customer's situation. (Head } \\
\text { of Facilities) }\end{array}$ \\
\hline & Fixed mindset & $\begin{array}{l}\text { Salespeople may have a fixed mindset about } \\
\text { certain things concerning the sales } \\
\text { interaction or the sales process. For example, } \\
\text { salespeople might talk too much or even be } \\
\text { pushy, ignoring customer cues on how to } \\
\text { interact with them. }\end{array}$ & $\begin{array}{l}\text { If [the salesperson] is too aggressive, pushy. } \\
\text { That they are, views and opinions are too } \\
\text { assertive, this is like this and so on. [...] not } \\
\text { sure if [they] know and understand this } \\
\text { organization so that it would work here. } \\
\text { (Sourcing Director) }\end{array}$ \\
\hline & Mental pressure & $\begin{array}{l}\text { Salespeople can be under high mental } \\
\text { pressure, as sales objectives are usually very } \\
\text { high, and on the other hand, many sales cases } \\
\text { do not result in sales and may be seen as } \\
\text { defeats. If these feelings are not adequately } \\
\text { addressed, salespeople may be less capable } \\
\text { of reading customer cues. }\end{array}$ & $\begin{array}{l}\text { In [our] work it is very straining when cases } \\
\text { aren't advancing or we lose them. Especially } \\
\text { when your own sales numbers are lagging } \\
\text { behind... that pressure is not good for you... } \\
\text { some kind of peer support would be } \\
\text { necessary. (Sales Representative) }\end{array}$ \\
\hline Sales process & $\begin{array}{l}\text { Insufficient social } \\
\text { support }\end{array}$ & $\begin{array}{l}\text { There might be insufficient social support } \\
\text { within the sales organization. As a result, } \\
\text { there might be less collaboration on customer } \\
\text { cases, and limited knowledge sharing. } \\
\text { Salespeople may not ask for advice, and they } \\
\text { don't learn from one another. }\end{array}$ & $\begin{array}{l}\text {... are afraid to ask for advice, or don't know } \\
\text { how to ask for advice, these kinds of things... } \\
\text { less experienced sellers might ask more } \\
\text { easily than experienced ones. An } \\
\text { experienced (seller) thinks that I should } \\
\text { know this, but I'm afraid to ask or something } \\
\text { else. (Sales Representative) }\end{array}$ \\
\hline
\end{tabular}




\begin{tabular}{|c|c|c|c|}
\hline \multirow[t]{2}{*}{$\begin{array}{l}\text { Sales } \\
\text { management } \\
\text { and } \\
\text { organizational } \\
\text { environment }\end{array}$} & $\begin{array}{l}\text { Overly strict internal } \\
\text { policies and guidelines }\end{array}$ & $\begin{array}{l}\text { If the internal policies and guidelines are too } \\
\text { strict, salespeople don't have enough degrees } \\
\text { of freedom. For example, salespeople might } \\
\text { be restricted by predefined services or } \\
\text { solutions. This can come across as a fixed } \\
\text { mindset or arrogant selling that doesn't listen } \\
\text { but only tries to persuade customers behind } \\
\text { these fixed services or solutions. }\end{array}$ & $\begin{array}{l}\text { I will remember if someone has given a } \\
\text { negative [impression]. If someone is very... } \\
\text { nervousness doesn't bother me at all, but a } \\
\text { sort of arrogance, or a person who asks but } \\
\text { doesn't listen. That also stays in my mind. } \\
(C E O)\end{array}$ \\
\hline & $\begin{array}{l}\text { Unsuited outcome-based } \\
\text { sales management } \\
\text { systems }\end{array}$ & $\begin{array}{l}\text { Outcome-based sales management and } \\
\text { numbers-centric management systems create } \\
\text { incentives that lead to salespeople } \\
\text { emphasizing quantity instead of quality. For } \\
\text { example, measuring the number of customer } \\
\text { calls can lead to many easy calls and } \\
\text { decrease time spent on more difficult or } \\
\text { riskier customers with large potential. This } \\
\text { may lead to salespeople offering canned } \\
\text { solutions to tackle more prospects in a given } \\
\text { time. }\end{array}$ & $\begin{array}{l}\text { One can see that they often come to meet just } \\
\text { because they have to do lot of visits. (CEO) }\end{array}$ \\
\hline
\end{tabular}




\section{Table 4}

\section{Antecedents Related to the Formation of a Follow-up Gap}

\begin{tabular}{|c|c|c|c|}
\hline Domain & Antecedent & Explanation & Illustrative quotes \\
\hline \multirow[t]{2}{*}{ Salespeople } & Fixed mindset & $\begin{array}{l}\text { Salespeople may have a fixed mindset about } \\
\text { certain things concerning the sales } \\
\text { interaction or the sales process. For example, } \\
\text { they might expect the customer to be the one } \\
\text { initiating the contact at certain points, like } \\
\text { calling with their decision on the sent offer. } \\
\text { However, the customer may expect } \\
\text { salespeople to be the active party. }\end{array}$ & $\begin{array}{l}\text { But anyway it will be accepted or it won't be } \\
\text { accepted, or it's possible that it takes some } \\
\text { time before the customer calls back that they } \\
\text { need [the service]. (Sales Manager) }\end{array}$ \\
\hline & Lack of perseverance & $\begin{array}{l}\text { Salespeople can lack perseverance when } \\
\text { pursuing customer cases. As a result, they } \\
\text { might prefer working on cases that seem } \\
\text { more accessible and easier to deal with } \\
\text { instead of cases that might be hard but more } \\
\text { lucrative. }\end{array}$ & $\begin{array}{l}\text { Sometimes you just see that the customer has a } \\
\text { bad day or something... Then I know it's not } \\
\text { going to work. If you don't have a connection, } \\
\text { there is almost nothing to do. I try to transfer } \\
\text { the case to someone else, and take another } \\
\text { [case]. (Sales Representative) }\end{array}$ \\
\hline \begin{tabular}{|l} 
Sales \\
interaction
\end{tabular} & $\begin{array}{l}\text { Contact person changes } \\
\text { during the sales process }\end{array}$ & $\begin{array}{l}\text { If the contact person at the customer } \\
\text { organization changes during the sales } \\
\text { process, the salesperson needs to adapt to } \\
\text { different service expectations and } \\
\text { communication styles. If the contact person } \\
\text { at the sales organization changes during the } \\
\text { sales process, it creates uncertainty for the } \\
\text { customer. The new salesperson needs to } \\
\text { adapt to the customer and communicate } \\
\text { more. }\end{array}$ & $\begin{array}{l}\text { In fact, the contact person changed there, so } \\
\text { maybe there was a pit, you know like it's one of } \\
\text { the pitfalls in sales when the contact person } \\
\text { changes. Then you should be extra active in } \\
\text { contacting the customer, to keep up the } \\
\text { contact. (Area Director) }\end{array}$ \\
\hline
\end{tabular}




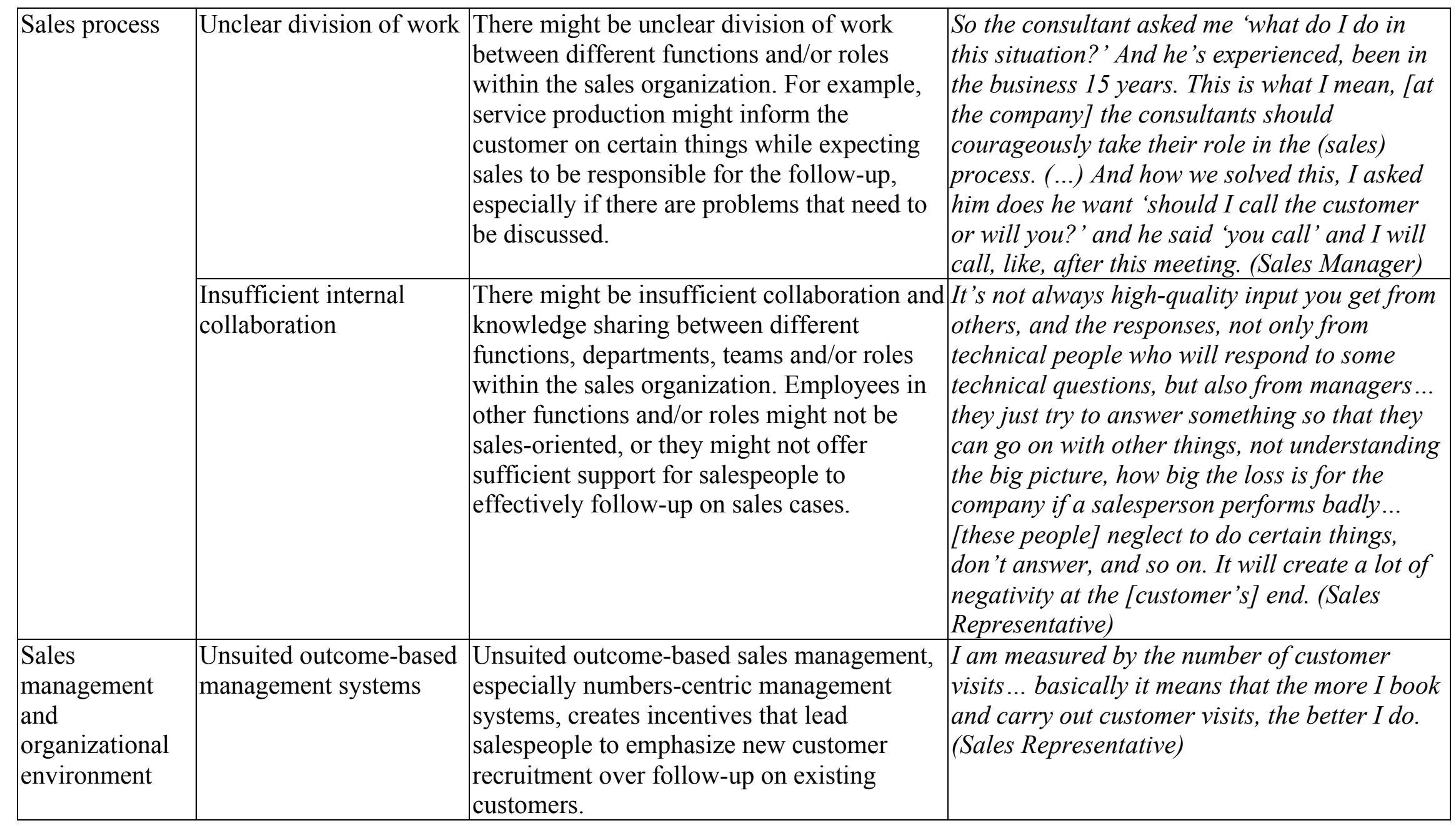




\section{Table 5}

Antecedents Related to the Formation of an Adaptability Gap

\begin{tabular}{|c|c|c|c|}
\hline Domain & Antecedent & Explanation & Illustrative quotes \\
\hline \multirow[t]{3}{*}{ Salespeople } & $\begin{array}{l}\text { Insufficient or erroneous } \\
\text { customer knowledge }\end{array}$ & $\begin{array}{l}\text { Salespeople have insufficient or erroneous } \\
\text { knowledge about the customer's context } \\
\text { (company, business, market etc.). Despite } \\
\text { this, salespeople might themselves to be } \\
\text { customer-oriented and understanding the } \\
\text { customer's overall situation. According to } \\
\text { customers, they don't understand the } \\
\text { market/processes/use context enough to truly } \\
\text { adapt the service or to support its } \\
\text { implementation. }\end{array}$ & $\begin{array}{l}\text { Although the person is very pleasant when } \\
\text { giving the pitch, what do they actually mean, } \\
\text { because salespeople are salespeople, and the } \\
\text { work is actually done by different people } \\
\text { altogether. And others produce the service, } \\
\text { so it's always an interesting point in a way, } \\
\text { what you can rely on when working with the } \\
\text { salesperson... the negotiations should } \\
\text { preferably include practical people who can } \\
\text { really give answers and talk about the } \\
\text { everyday work. (Head of Facilities) }\end{array}$ \\
\hline & Too strong vision & $\begin{array}{l}\text { Salespeople have a strong vision of how the } \\
\text { service is and are unable to change it. This } \\
\text { may be due a strong occupational identity. As } \\
\text { a result, salespeople don't want to change the } \\
\text { service according to what the customer needs } \\
\text { or wishes. }\end{array}$ & $\begin{array}{l}\text { I run into, or we run into like interior } \\
\text { designers, especially in these creative } \\
\text { occupations. [They] have such a strong } \\
\text { occupational identity. And when they are } \\
\text { selling certain services or solutions, they } \\
\text { don't allow, customers don't have a right to } \\
\text { change their vision. So that they alone are } \\
\text { right, even if it is, it should be the other way } \\
\text { around, that the customer is right. (Area } \\
\text { Director) }\end{array}$ \\
\hline & $\begin{array}{l}\text { Insufficient } \\
\text { interpersonal skills }\end{array}$ & $\begin{array}{l}\text { Salespeople might not have sufficient } \\
\text { interpersonal skills to read the cues the } \\
\text { customer is giving and/or adapt their selling } \\
\text { style accordingly. The customer may feel that } \\
\text { salespeople ignore their views and continue } \\
\text { with their own agenda. }\end{array}$ & $\begin{array}{l}\text { Sometimes I meet salespeople who try to } \\
\text { offer the whole range of things they have... to } \\
\text { them I say hold on... it might be too complex } \\
\text { thing to start with ... but they don't } \\
\text { understand it, [they] just continue on the } \\
\text { same course. (CEO) }\end{array}$ \\
\hline
\end{tabular}




\begin{tabular}{|c|c|c|c|}
\hline \multirow[t]{3}{*}{\begin{tabular}{|l} 
Sales \\
interaction
\end{tabular}} & $\begin{array}{l}\text { Contact person changes } \\
\text { during the sales process }\end{array}$ & $\begin{array}{l}\text { If the contact person at the sales organization } \\
\text { changes during the sales process, it creates } \\
\text { uncertainty for the customer. If the contact } \\
\text { person at the customer organization changes } \\
\text { during the sales process, the salesperson } \\
\text { needs to adapt to different service } \\
\text { expectations and communication styles. } \\
\text { Salespeople may also need to deal with the } \\
\text { internal politics of the customer organization } \\
\text { (power games, leadership disputes etc.) }\end{array}$ & $\begin{array}{l}\text { I somehow interpret it so that his superior, } \\
\text { who initially bought this, and who gave [the } \\
\text { deal] for this guy to do... there is a } \\
\text { leadership challenge between them. And then } \\
\text { if he wants to be uncooperative with us, we } \\
\text { just have to bear with him and soldier on. } \\
\text { (Specialist) }\end{array}$ \\
\hline & $\begin{array}{l}\text { Insufficient face-to-face } \\
\text { time }\end{array}$ & $\begin{array}{l}\text { Customers want less face-to-face time and } \\
\text { are more price-oriented. Without sufficient } \\
\text { face-to-face, salespeople don't have enough } \\
\text { understanding of customer needs to adapt the } \\
\text { service. }\end{array}$ & $\begin{array}{l}\text {...we work a lot on the phone, taking requests } \\
\text { for offers [...] And I already referred to this } \\
\text { [earlier], that when you need to send offers } \\
\text { by email. (Sales Manager) }\end{array}$ \\
\hline & Lack of connection & $\begin{array}{l}\text { Customers don't share enough details about } \\
\text { their business or future plans. Salespeople are } \\
\text { unable to adapt the services or solutions they } \\
\text { are offering due to lack of understanding or } \\
\text { information. }\end{array}$ & $\begin{array}{l}\text {... they were not telling about what they are } \\
\text { doing. Or what they are aiming for, they } \\
\text { were not opening out what is challenging for } \\
\text { them. (Specialist) }\end{array}$ \\
\hline Sales process & $\begin{array}{l}\text { Insufficient internal } \\
\text { collaboration }\end{array}$ & $\begin{array}{l}\text { There might be insufficient collaboration and } \\
\text { knowledge sharing between different } \\
\text { functions, departments, teams and/or roles } \\
\text { within the sales organization. For example, } \\
\text { salespeople don't share knowledge on how to } \\
\text { act with certain customers (e.g. if a verbal } \\
\text { agreement is enough to conclude a sale with a } \\
\text { particular client, or if things need to be } \\
\text { written down). }\end{array}$ & $\begin{array}{l}\text { I told to her to call that person, our } \\
\text { colleague, there in, and ask whether he } \\
\text { knows this customer better, and what would } \\
\text { he advise us to do in this kind of situation. } \\
\text { (Sales Manager) }\end{array}$ \\
\hline $\begin{array}{l}\text { Sales } \\
\text { management } \\
\text { and }\end{array}$ & $\begin{array}{l}\text { Overly strict internal } \\
\text { policies and guidelines }\end{array}$ & $\begin{array}{l}\text { If the internal policies and guidelines are too } \\
\text { strict, salespeople don't have enough degrees } \\
\text { of freedom. For example, if salespeople are } \\
\text { required to follow certain procedures, e.g. fill }\end{array}$ & $\begin{array}{l}\text { We need to fill-in the blue sheets and the gold } \\
\text { sheets etc., and sometimes we need to get } \\
\text { approvals from internal steering teams in } \\
\text { order to proceed. I don't like it at all; it }\end{array}$ \\
\hline
\end{tabular}




\begin{tabular}{|c|c|c|c|}
\hline \multirow[t]{2}{*}{$\begin{array}{l}\text { organizational } \\
\text { environment }\end{array}$} & & $\begin{array}{l}\text { in certain documents or get approval from } \\
\text { higher levels within the organization at } \\
\text { certain points in the sales process. These } \\
\text { procedures might come across as salesperson } \\
\text { inflexibility to the customers. }\end{array}$ & $\begin{array}{l}\text { doesn't fit to my work requirements. (Sales } \\
\text { Representative) }\end{array}$ \\
\hline & $\begin{array}{l}\text { Insufficient focus on } \\
\text { salesperson expertise }\end{array}$ & $\begin{array}{l}\text { Salespeople might often be seen as } \\
\text { 'generalists' who deal with all types of } \\
\text { customers and are not specialized to certain } \\
\text { markets/businesses etc. As a result, } \\
\text { salespeople don't have sufficient resources to } \\
\text { develop their expertise in order to adapt the } \\
\text { service offering to different customers, and } \\
\text { tend to offer standard solutions. }\end{array}$ & $\begin{array}{l}\text { After a few moments, you see that it is the } \\
\text { same thing that they try to sell to } \\
\text { everybody... they offer the whole range at } \\
\text { once... they pretty much start from their } \\
\text { solutions. (Sourcing Director) }\end{array}$ \\
\hline
\end{tabular}


Figure 1

Antecedents to Theory-Practice Gaps in Sales

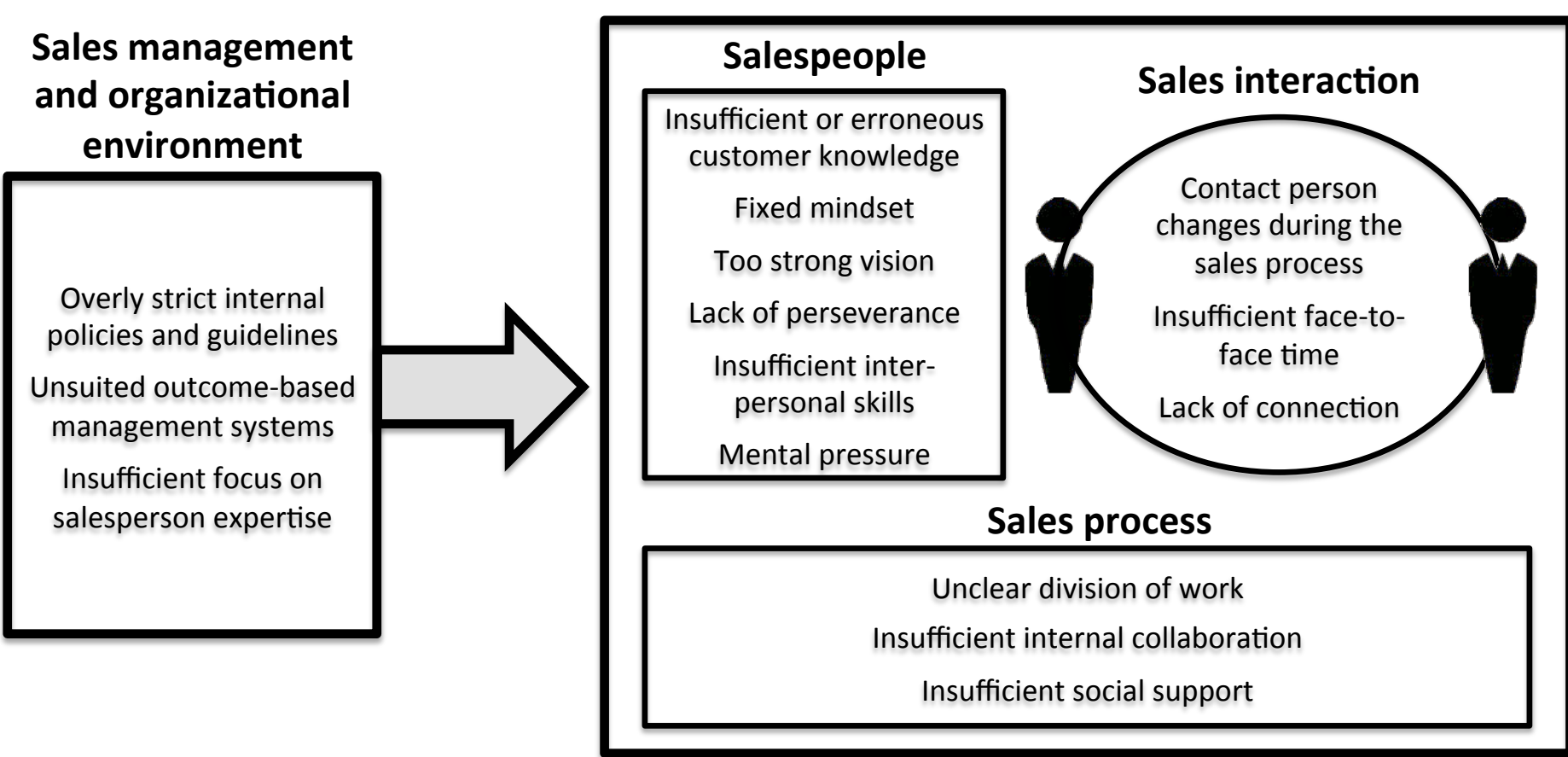

